\title{
Sociotechnologies, sovereignty, and transdisciplinary research
}

\author{
Michael Christie \\ College of Indigenous Futures, Arts \& Society, Charles Darwin University \\ michael.christie@cdu.edu.au
}

Keywords: sociotechnologies; language work; Indigenous sovereignty; academic research practices

\begin{abstract}
When researchers from an academic knowledge tradition undertake transdisciplinary research - that is, research which takes seriously knowledge practices quite alien to the disciplines of the academy - science and technology studies can help unpick some of the assumptions which are embedded in their research practice. The analysis of sociotechnologies, which are understood as phenomena which are indivisibly both social and technical, allows a researcher in the many unique contexts of Australia's remote Northern Territory, to take seriously the understandings and methods of Aboriginal knowledge authorities, and work collaboratively and generatively with them. In this paper, examples from research collaborations in education, language, politics, housing and health in the Northern Territory explores the utility of the STS analytic concept 'sociotechnology'. In each example our methods identify tensions between practices - including epistemics - which remain unresolved except insofar as they may point towards strategies to address problems of the moment. Aboriginal sovereignty can be seen as a key to understanding the position of the academic researcher in transdisciplinary work, and conceptually sociotechnology offers a means to respect and engage with the ancestral knowledge practices and authority of Aboriginal elders.
\end{abstract}

\section{Introduction}

How might science and technology studies be useful in transdisciplinary research in Northern Australia? My contribution to this discussion centres on the notion of sociotechnology which allows us to "unpick" some assumptions embedded in Western knowledge traditions, and provides resources for new forms of situated interdisciplinary, multidisciplinary and transdisciplinary research work. Exploring sociotechnologies allows us to interrogate some of the assumptions which we, within the western academic tradition, bring to our research, and opens ways for better engaging with Indigenous knowledge practices on the terms of their owners. Many Aboriginal knowledge authorities in the far north of Australia continue to live on and care for their ancestral lands, along with their many different languages and ceremonial practices and have never ceded their sovereignty. They work hard to maintain their unique social, cultural and political practices, and to remember and revitalise their many particular pasts. And they bring their cultural and political resources to the postcolonial work of growing up new generations of young people in contemporary Australia.

For university researchers and consultants, taking these practices seriously entails transdisciplinary research, that is research which transcends the usual limits of knowledge work found in the academy, including its rules and practices, and takes seriously entirely 
different knowledge traditions and their rules and practices - in this case those of Yolnu Aboriginal people of Arnhem Land in the Northern Territory with whom I have been working for nearly fifty years.

In the first section of the paper I introduce the notion of sociotechnology as I explore some Yolnu understandings of language and knowledge work which we have learnt in our research going back over many years. In the second section I briefly explore two examples of collaborative transdisciplinary research where taking seriously both Yolnu philosophies and knowledge practices, and the cultural and historical contingency of western academic and governance practices opened up possibilities for new ways of negotiating Aboriginal health and housing. I conclude with a brief comment on the ongoing issues of the use of Aboriginal languages in the parliament of the Northern Territory where we work.

\section{Part 1: Sociotechnologies}

Sociotechnologies can be defined as "processes in which the social and the technical are indivisibly combined" (Vojinović \& Abbott, 2012, p. 164). In the examples I bring to the fore in this paper, I point to collaborative work with Yolnu Aboriginal knowledge authorities which may help us deepen and expand our collaborative transdisciplinary work. For example, thinking of 'a language' as a sociotechnology provides a useful way of taking seriously tensions between linguistic understandings of language which tend to focus on the technical, and Aboriginal understandings which are concerned with the cultural, social, political and the sacred (Christie, 1993). In each, the social is indivisible from the technical - that is a characteristic they share. Understanding sociotechnical phenomena deepens and problematises our understanding of borders and boundaries as 'lines' mobilised through particular enactments of inside and outside, similarity and difference.

\section{Translating and Interpreting as sociotechnical practices}

I begin by teasing out my understanding of sociotechnology a little by referring to Yolnu insights into the relationship between translating and interpreting. In conventional Western linguistic thinking, translating and interpreting are the same process, except that translating is working with written texts, and interpreting works with oral texts. They both work with the idea that at issue is the converting of a representation of a state of affairs from one language to the other. The assumption that the external state of affairs remains unchanged, that language cuts nature at its joints, and that translation is always possible with enough skill and work, entails a particular sort of boundary making: the commensurability of different languages is assumed, while at the same time the radical difference and distinction between language as such and reality as such, is drawn and enforced. ${ }^{1}$

In my experience however, Indigenous language workers take translation and interpreting as quite different practices. According to their view, in translation one does one's best to render a text from one language to another, without adding anything that is not in the original, and without leaving out anything that was in the original, all the while preserving as much as

\footnotetext{
1 For example, the Australian National Accreditation Authority for Translators and Interpreters (NAATI) which accredits Aboriginal interpreters in the Northern Territory makes no such distinction. An internet search for any differentiation between translation and interpretation in the academic literature revealed nothing.
} 
possible of the style or flavour of the original - contextuality matters. We had much fun doing that sort of translation in the Literature Production Centres of NT bilingual schools.

Interpreting, on the other hand, is to be understood as working two language systems together to build agreed understandings here and now. This is a view which accords closely with the model and imperative for knowledge production in formal education that is given by Yolnu elders - the metaphor of 'garma' is salient (see further below). Here language is quite a different sociotechnical phenomenon than in translating. Utterly material and performative rather than representational (representation being just another form of performance), language is being used carefully to create new ways and worlds for going on together, following on from the ancestors who made the knowable world through their singing, calling and crying.

\section{Education as sociotechnology}

I began working as teacher-linguist in a bilingual education program at Milingimbi in the 1970s. In the early bilingual programs we (the non-Indigenous teachers and curriculum developers) happily continued with our enlightenment assumptions of the nature and practice of education. We left intact our practices of pedagogy as transmission of knowledge, changing only the languages of instruction, and developing a literature in those languages. Ten years later, at Yirrkala, we were introduced to a quite different pedagogy and philosophy of education by local elders working with teachers to 'Aboriginalise' the curriculum. We were given an ancient Aboriginal epistemology and practice of education which came to be known as 'garma' - after the ceremonial spaces and practices used for garma Yolnu ceremonies (Marika-Munuggiritj et al., 1990; Ngurruwutthun, 1991). Aboriginal practices of language, of performance, of place, of identity and growing up children, cometogether at the garma, and non-Indigenous and Indigenous people are invited to participate respectfully and in good faith, in making knowledge and other agreements, on those terms. Every garma is on someone's land, and people who come to the garma have their own backgrounds, their own stories, ways of talking and authority. The garma epistemology was a precious gift which allowed non-Yolnu knowledge practitioners to contribute seriously to the life of the community, while always under the sovereign authority of the elders. ${ }^{2}$

I want to emphasise how understanding education as a sociotechnology allows us to discern key differences between the Aboriginal philosophy and practices of both-ways education and the western formal education to which most of us who have ever been to school have been subjected. Some of the key differences revealed in a commitment to garma education are: Students and teachers must speak their own language strongly and perform their history as a sign of their knowledge and authority. Truth claims are performed and choreographed always in collaboration with others from other places. Knowledge is always situated and produced and performed collaboratively from the ground-up. Western knowledge is useful as it is performed respectfully under the watchful guidance of the senior elders who have authority over the garma space and its practices, collaboratively building ways of going on together. Curriculum documents, along with policies, practices and plans, must emerge from collective action, they cannot precede it. Our GroundUp research practice, ${ }^{3}$ following the principles of garma, also works diligently with fundamental but generative differences.

2 It is good to remember that garma is only one of a range of 'both-ways' or 'two-ways' education philosophies and practices developed by Aboriginal knowledge authorities during and after the days of bilingual education in the Northern Territory, and that the Batchelor Institute of Indigenous Tertiary Education continues to celebrate and implement 'both-ways' in their teaching and research work.

3 GroundUp is a research group and practice within the Contemporary Indigenous Knowledge and Governance Group, at the Northern Institute, Charles Darwin University. See http://groundup.cdu.edu.au/ 


\section{Part 2: Collaborative transdisciplinary research}

\section{Health communication}

When I first came to Darwin after living in Arnhem Land, I was invited to work on a research project addressing the problem of communication breakdown in the context of treatment for Yolnu with kidney disease. My research colleague was Betty, a Yolnu linguist and renal patient. On our first day, we were asked to translate into Yolnu language a complex biomedical English statement about kidney function, disease and treatment: corpuscles, nephrons, dialysis, and so on. It was an impossible task, and very frustrating. The medical practitioners' blithe belief in the fundamental truth of the biomedical body, and their parallel commitment to the possibility of precise translation had us at our wits' end. Trying to find a way of moving the text from English into Yolnu was very difficult to say the least. I could see that whatever Yolnu text we came up with would simply not sustain a back translation. Every time we got stuck, Betty started to tell stories elucidating or exploring the concept at hand. It was this resourcefulness that eventually gave us a way forward. Betty re-defined effective health communication as 'sharing the true stories': discussions around language and bodies, biomedical truths and informed consent. This became the name of the research project. ${ }^{4}$

'Sharing the True Stories' demonstrated how practices of developing informed consent for treatment could be generated in a garma-style setting where the quite different, even incommensurable understandings of the body, of health, sickness, treatment, life and agency were worked together carefully and respectfully (Cass et al., 2002). Paying attention to languages as simultaneously social and technical, paying attention to socio-materialities of spaces, of various roles, of different medical specialisations, and particularly family members, provided useful ways of negotiating insides and outsides, boundaries and borders, and gave Yolnu the chance to bring their Yolnu bodies into negotiation as part of the conversation alongside biomedical bodies. Who suffers when people are sick? The individual? The family? The world? The spirit? We began to see the technocratic undertaking of simply translating a biomedical text into an Aboriginal language as a sort of an invasion or violation of the sovereign bodies of ailing Yolnu, and their peoples and places. The nutritionist, the nephrologist, the social worker, the family, the clan elders, and the institutional arrangements of spaces and roles, can be worked together in good faith to develop informed consent together using different languages in quite different ways.

The work Betty and I did together was part of a difficult, often fraught and contested research collaboration. In hindsight, I find it is useful to understand this collaboration through the rubric of sociotechnology. How is each participant in the collective action of renal care always both social and technical? In a follow up project, we produced a collaborative design for what we called the 'touch-pad body', a screen based conversation facilitator which presents a zoomable semi-transparent body in an environment. It is ambiguous enough to interrupt the biomedical certainties of health professionals and gives the opportunity for Aboriginal patients and their families to develop conversations in different languages, circulating around and towards informed understandings and consent (Christie \& Verran, 2014). 


\section{Housing}

In more recent years, we have come to refer to our garma-style research methods as 'GroundUp' - emphasising the situated, collaborative, generative aspects of our work. GroundUp research addressing the intractable problem of housing in remote Aboriginal communities provides another example. Especially since the compulsory acquisition by the NT Government of all Aboriginal housing stock previously owned and administered by Indigenous Community Housing Organisations, the design and provision of housing has been increasingly seen as a technical problem and a bureaucratic responsibility. Some of our research work in this area was conducted in Yolnu languages at Galiwin'ku. To the Yolnu, housing is indivisibly both social and technical. One senior Djambarrpuynu elder stood outside his house at Galiwin'ku and said to the video camera: "I call this my house Rinydjalnu because Rinydjalnu is the resting place of our totemic ancestral Djambarrpuynu shark. This is where I rest, and where my people are safe, and people know that I have a right and reason to be here." He was deliberately repudiating the technocratic understanding of housing manifest in government decision making. According to Yolnu, housing participates in governance - they are not separate things. Housing can play its role in good governance if it relates properly to ancestral precedents determining who and where you are, and how you are related to the place where your home is standing.

As part of the same research, senior Yolnu were invited to draw illustrations of houses and shelters, then and now, and to reflect upon the nature and viability of contemporary housing arrangements. One produced a picture of a house as Raypirri'. The word raypirri' is generally used these days to imply a top-down disciplinary practice, especially for telling feckless young people how to behave themselves. But here, you see that well-designed, decently inhabited houses themselves perform raypirri'. That is, they participate through their structures, their positioning, their names, and their orientation towards traditional lands in good governance if they are designed, erected and inhabited under the guidance of knowledgeable elders and cultural authorities. Houses have the power to ensure healthy behaviour. Children are safe, young men and women are guided and supervised, old people are visible and remembered, and can see and be heard all around.

\section{Language in Parliament}

Finally, a few words on the current issue of language in the Northern Territory's parliament. Mark Yiniya Guyula is currently the Member of the Legislative Assembly representing the people of the Arnhem Land electorate. A vast majority of people in his electorate speak one of several dozen Yolnu languages, and Yiniya speaks his own language Djambarrpuynu with the authority of an elder. When he speaks his language, he speaks with the power of his ancestors who created his land and its species by talking, singing and crying in that particular language. (When they moved on to a new place in their creation journey, they changed their language to a different one which belongs to the people of that place which they then left behind before moving on). Yiniya feels it is important for him to speak in his own language first when he speaks in parliament, even though he is very capable to speak English subsequently, and to give an interpretation of what he has already said in his own language. But the Standing Orders Committee with its own highly utilitarian understanding of the sociotechnology of language, has agreed upon a rule that requires everyone to speak English and only English in parliament.

Much of the discussion around this issue has centred around the rights of Indigenous peoples, but also the availability of interpreters and precedents for native language use in 
other countries' parliaments. But at a CDU seminar, Yiniya himself made clear that such arguments - which assume the primary function of language to be representation - quite miss the point about language, identity, place and authority. He said: "The reason why I want to speak Yolnu matha is because it's my language and the language of the people I represent. When I speak it, I acknowledge the land and the people, and I know and show that I am the right person to represent them." Yiniya is quite capable of speaking good English. He doesn't need an interpreter. He is making a particular claim about language, sovereignty, and his right to represent his people, which eludes those who focus on the technical-communicative functions of language. ${ }^{5}$

\section{Conclusion}

I have presented here only a few of many examples of working from the ground up, on problems of the moment, to make agreement and undertake robust and equitable research, while at the same time taking seriously Aboriginal sovereignty. The notion of sociotechnology provides a conceptual analytic tool whereby we can stand back from the Western assumptions which saturate our thinking, and look at the politics and the practices of making a difference.

\section{References}

Cass, A., Lowell, A., Christie, M., Snelling, P. L., Flack, M., Marrnganyin, B., \& Brown, I. (2002). Sharing the true stories: improving communication between Aboriginal patients and healthcare workers. Medical Journal of Australia, 176(10), 466-470.

Christie, M. (1993) Yolngu linguistics. Ngoonjook (8), 58-77.

Christie, M., \& Verran, H. (2014). The touch pad body: A generative transcultural digital device interrupting received ideas and practices in Aboriginal health. Societies, 4(2), 256-264.

Marika-Mununggiritj, R., Maymuru, B., Mununggurr, M., Munyarryun, B. T., Ngurruwutthun, G., \& Yunupingu, Y. (1990). The history of the Yirrkala community school: Yolngu thinking about education in the Laynha and Yirrkala area. Ngoonjook, (3), 32-52.

Ngurruwutthun, D. (1991). The Garma Project. In R. Bunbury, W. Hastings, J. Henry and R. McTaggart. (Eds). Aboriginal pedagogy: Aboriginal teachers speak out. Melbourne: Deakin University Press. 107-122.

Vojinović, Z., \& Abbott, M. B. (2012). Flood risk and social justice: from quantitative to qualitative flood risk assessment and mitigation. London: IWA Publishing.

5 Since this paper was written, the NT Legislature Standing Orders Committee agreed to Yiniya's request. See https://nit.com.au/yingiya-mark-guyula-makes-history-addressing-nt-parliament-in-language/ 